\title{
The Relevance Of Discretionary Disclosures: Predictive Value Versus Feedback Value
}

\author{
William Wilcox, Northern Colorado University, USA \\ Kevin Berry, University of Alaska Fairbanks, USA \\ David O'Bryan, Pittsburg State University, USA \\ Jeffrey J. Quirin, Wichita State University, USA
}

\begin{abstract}
This study contributes to the body of literature examining the role of discretionary disclosures. The primary theoretical contribution is a distinction between predictive value and feedback value. We use the Ohlson Model and examine the role of information as an endogenous variable in modeling the impact of disclosures on returns, which is a key methodological contribution to this stream of literature. Using a sample of 121 firms from the AIMR's Corporate Information Committee for 1982-1994 we find that the expanded firm disclosures did possess predictive value, but they did not possess significant feedback value. These results have important policy implications since the relative costs and benefits of disclosures with predictive value differ from those with feedback value.
\end{abstract}

Keywords: discretionary disclosures, predictive value, feedback value, Ohlson Model

\section{INTRODUCTION}

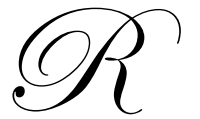

esearch studies on discretionary disclosures generally assume that managers of the firms have more information about the firms' past and future activities than do external parties. While management is required to disclose information to the market through annual and quarterly reports, some firms are willing to provide additional information to the investing public. These discretionary disclosures can include, but are not limited to, other non-required published materials, improved investor relations, and improved communications with financial analysts. In evaluating firms' corporate disclosure practices, the Association for Investment Management and Research (AIMR), through its Corporate Information Committee, reported the following about some of its 1993-1994 award winners:

"The comments that propelled Equitable into the top position revolved around a strong president's letter and a very thoughtful discussion of where the company has been and where it is going. The letter laid bare the company's strengths and weaknesses and provided a good and concise description of its strategic planning."

"The package of quarterly information Boise Cascade made available, which included a fact book, was considered particularly noteworthy. In all respects, the program demonstrated a commitment to providing accurate, accessible, and timely financial information."

"In addition, (Home Depot's) top management maintained a high level of accessibility throughout the year, enabling the investment community to stay current on the company's developments."

These different types of discretionary disclosures are aimed at reducing the information asymmetry between the managers of the firms and the external stakeholders. A key distinction among these different types of disclosures is that some types are very forward-looking, focusing on the company's future directions. Other types of disclosures are aimed at providing investors with more detailed information about the company's past and current financial and operating performance. 
In exchange for these expanded disclosures, firms should receive benefits due to the reduction of information asymmetry between the firms' managers and the external investors. The benefits examined in accounting research have included such things as increased stock liquidity (Healy et al. 1999; Welker 1995), lower cost of capital (Poshakwale and Courtis 2005; Botosan and Plumlee 2002; Sengupta 1998; Botosan 1997), efficiency and signal informativeness (Shaw 2003; Pae 2002; Chen et al. 2002; Dutta and Trueman 2002), stock-based compensation (Nagar et al. 2003), and correction of market undervaluation (Healy et al. 1999). While previous studies have focused on benefits due to expanded disclosures, there is still a need to capture the impact of the relevant attributes of information on firm valuations and returns. Our study contributes to this body of research by empirically examining the role of discretionary disclosures in a theoretical model, focusing on the relevant characteristics of accounting information. This study provides two primary contributions to the stream of research aimed at examining the consequences of expanded discretionary disclosures.

The first contribution is the examination of the effect of firms' discretionary disclosures using the Ohlson Model (Ohlson 1995; Feltham and Ohlson 1995). Botosan (1997) was the first study to examine the impact of disclosures using an accounting based valuation formula, but her study considered the impact of information only as an exogenous variable. Using the "linear information dynamic" in the Ohlson Model, this study empirically examines the role of information as an endogenous variable in modeling the impact of disclosures on returns. This is an important methodological improvement because if firms' disclosures are correlated with their reported accounting numbers, the inferences drawn from statistical analysis may be misleading. The structural form of the "linear information dynamic" in the Ohlson Model would indicate that this is an important consideration.

Second, the main contribution of this study is the evaluation of predictive value and feedback value in firm disclosures. In the Ohlson Model, the linear information dynamic assumes that non-accounting information flows through abnormal earnings in future periods if it is value-relevant (Lundholm 1995). ${ }^{1}$ Therefore, non-accounting information using the Ohlson Model would only comprise those disclosures that possessed predictive value. In addition, disclosures that do not flow through abnormal earnings in future periods, but which still assist decision makers in assessing the value of the reported accounting information (i.e., current financial results) would possess feedback value. ${ }^{2}$

The distinction between these two dimensions of relevance is critical from a policy-setting perspective. If there are benefits to expanded disclosures, it is important to identify which types of disclosure result in the benefits. Disclosures that possess predictive value may be less reliable than disclosures that possess feedback value. ${ }^{3}$ This lower degree of reliability may result in greater inherent costs, due to the potential for lawsuits if the future events do not materialize, to the loss of competitive advantage, etc. Therefore, it is important to determine if the identified benefits to expanded disclosures are attributed to predictive value or feedback value.

The results of this study found that the relevant information benefits of expanded firm disclosures primarily consisted of predictive value as compared to feedback value. For firms that expanded their discretionary disclosures, relative to those that decreased their discretionary disclosures, the market did assign a higher valuation multiple on only the current period's abnormal earnings. This finding was similar to what was reported in previous studies (Healy et al. 1999). However, when including future earnings in the returns model, we found that all of the returns benefits were better reflected on the future earnings, and that the current period results were not significantly different between the two categories of firms. Therefore, the feedback component of relevant information quality did not have a significant influence on the firm's returns.

\footnotetext{
${ }^{1}$ Non-accounting information comprises all information that would not be included in the current period's general purpose financial statements. Non-accounting information would include things such as the number of backorders, which could potentially translate into sales in the subsequent period, or detailed segmental information, which might not have any impact on future performance. In the context of the Ohlson Model, the value-relevant non-accounting information would include only the information on the back orders.

${ }^{2}$ Because reported accounting information provides results of prior firm activities, it is our premise that the predominant information contained in the earnings and book value numbers is comprised of feedback value.

${ }^{3}$ The ingredients of reliability are verifiability, representational faithfulness, and neutrality. Because of the forward-looking nature of disclosures that possess predictive value, the characteristics of verifiability and representational faithfulness have a greater potential of being violated.
} 


\section{Hypotheses Development}

In evaluating the role of both accounting and non-accounting information in firm valuation and returns, the Ohlson Model will be employed to provide a theoretical framework. Using the clean surplus restriction, Ohlson (1995) identifies the valuation formula as:

$$
P_{t}=y_{t}+\sum_{\tau=1}^{\infty} R_{f}^{-\tau} E_{t}\left[\tilde{x}_{t+\tau}^{a}\right]
$$

where $P_{t}$ is the current period price, $y_{t}$ is the current period book value of equity, $R_{f}$ is the risk free interest rate, and $x_{t}^{a}$ is the current period abnormal earnings (see Ohlson 1995 for a discussion of the model). A final assumption formulated the information dynamics of the model, in which abnormal earnings, $x_{t}^{a}$, and information other than abnormal earnings, $\mathrm{v}_{\mathrm{t}}$, are specified as:

$$
\begin{aligned}
& { }^{a}=\omega x_{t}^{a}+v_{t}+\varepsilon_{1 t+1} \\
& v_{t+1}=\mathcal{w}_{t}+\varepsilon_{2 t+1}
\end{aligned}
$$

where the disturbance terms are mean zero and uncorrelated with other variables in the model. In this model, Ohlson defines $\mathrm{v}_{\mathrm{t}}$ as a summarization of all value relevant events that have yet to have an impact on the financial statements. 'Such information bears upon future (abnormal) earnings independently of current and past (abnormal) earnings.' (Ohlson 1995, p. 668) Therefore, it must become earnings sometime in the future if it is value-relevant. This results in the final linear solution of the Ohlson Model (Ohlson, 1995)

$$
P_{t}=y_{t}+\alpha_{1} x_{t}^{a}+\alpha_{2} v_{t}
$$

Contemporaneous returns can be measured by simply dividing both the left-hand side and all of the elements on the right-hand side by prior period price.

As identified in the Ohlson Model, the non-accounting information, $\mathrm{v}_{\mathrm{t}}$, is comprised of information that will ultimately become abnormal earnings in future periods. This information will have predictive value as identified in SFAC No. 2. If the firms' managers want to disseminate more information that contains predictive value, the market will be able to adjust its expectations of future performance so that the market's perceived future expectations will be similar to the managers. Previous research has theorized that managers have incentives to expand their disclosures when the firm is undervalued (Healy et al. 1999; Healy and Palepu 1993; Verrecchia 1990). Therefore, the production of non-accounting information, as per the Ohlson Model, would be directly associated with future abnormal earnings. And if future abnormal earnings are directly associated with firm returns, we can expect the coefficient on $\mathrm{v}_{\mathrm{t}}$ to be positively associated with a change in disclosures. This leads to the first hypothesis, as stated in the alternative form,

Hypothesis 1: The change in the predictive value of firms' accounting disclosures will be directly associated with the firms' returns.

In this instance, because the change in disclosures is directly associated with future abnormal earnings, the statistical tests will examine the relationship of the disclosure variable and firm returns.

Ohlson (1995) and Lundholm (1995) both note that if non-accounting information is value-relevant, it must become abnormal earnings in the future. However, feedback value is a category of non-accounting information that is relevant for user decision-making, but may not become abnormal earnings in the future. The Association for Investment Management and Research (AIMR), through its Corporate Information Committee, evaluates a small number of firms and provides a ranking of the firms' corporate disclosure practices. While the AIMR reports stress future-looking disclosures, such as management's discussion of goals in the annual report, they also consider other 
items that focus more on past and current results, such as the level of detail in quarterly reports and the publication of long-term historical summaries. These types of voluntary disclosures would be more useful in evaluating the current or prior periods' performance of the company.

While the role of feedback value is not clearly specified in the Ohlson Model, disclosures that possess feedback value are designed to provide external parties more detailed information about the firm's past and current results. Financial analysts who follow the company may have incentives to have timely and detailed information about the current period's results to provide to their clients. Furthermore, if the market perceives a firm's current period's results to be noisy relative to the true economic performance of the firm, a higher cost of equity capital may be imposed due to the greater degree of risk (Diamond and Verrecchia 1991). By expanding disclosures that possess feedback value, the managers of firms may reduce the noise in the accounting data, resulting in higher valuations (and returns), given the same reported accounting information. Because the disclosure changes are expected to have a direct impact on the association between returns and the published accounting data, $y_{t}$ and $x_{t}^{a}$, the second tested hypothesis, as stated in the alternative form, is:

Hypothesis 2: The change in feedback value of firms' accounting disclosures will be directly associated with the firms' relationships between returns and reported accounting data.

Because the change in disclosures is expected to reduce the information asymmetry associated with the reported accounting data, the statistical tests will examine the association between the accounting data and firm returns to see if there is a difference for firms that expanded their disclosures.

\section{Sample Selection}

The annual reports of the AIMR's Corporate Information Committee for 1982-1994 provide the information for firms' financial disclosure ratings, or non-accounting information, in this study. In measuring a firm's disclosures, this study will use a relative industry ranking $\left(R I R_{i t}\right)$ for each firm and year in the period of study. This calculation helps to eliminate measurement error across different industries and time periods (see Healy et al. 1999 and Lang and Lundholm 1993 for further discussion). The computation of a firm's RIR is as follows:

$R I R_{i t}=\frac{N_{i t}-R A N K_{i t}}{N_{i t}-1} \times 100$

where $R A N K_{i t}$ is the rank of firm i's disclosure score in period t, and $N_{i t}$ is the number of firms in firm i's industry in period t. Similar to Healy et al. (1999), this study examines sustained increases in firms' disclosures to capture the benefits from a change in firm disclosure policies. By focusing on changes in average relative ratings, rather than annual changes, we reduce the likelihood of examining firms that have large increases in ratings that reverse in the subsequent year. ${ }^{4}$ Because this study will be examining changes in a firm's average relative ranking, the change in a firm's relative rankings $\left(C R R_{i t}\right)$ will be computed as follows:

$$
C R R_{i t}=\frac{1}{3} \sum_{\tau=t}^{t+2} R I R_{i \tau}-\frac{1}{2} \sum_{\tau=t-2}^{t-1} R I R_{i \tau} \text { for } \mathrm{t}=1982, \ldots, 1994
$$

where $\mathrm{t}$ is the period of increased disclosures. A two-year average of $R I R$ prior to the change and a three-year average following the change was used so that we may better capture firms who have changed their disclosure policy (Healy et al. 1999). The highest decile of firms based on the $C R R_{i t}$ was selected to represent firms with

\footnotetext{
4 As shown in equation (3), Ohlson's linear information dynamic defines the process for non-accounting information as autoregressive. In order to examine the policy implications of expanded disclosures, it is important to identify those firms whose disclosures do not follow an autoregressive process.
} 
large increases in their disclosure policy. In addition, some firms which had large one-year changes in disclosure followed by an almost complete reversal in a following year were eliminated. This resulted in a final sample of 134 firms.

In order to test the effect on firms that have increased their discretionary disclosures, another category of firms was selected for comparison purposes. This group consists of firms who have had large sustained decreases in their disclosure ratings. Because these firms no longer posses some of the benefits from expanded disclosures, their inclusion should help to identify the benefits from accounting disclosures. The comparison group was composed of the smallest decile of firms based on the $C R R_{i t}$. In addition, some firms which had large one-year changes in disclosure followed by an almost complete reversal in a subsequent year were eliminated from the analysis. This resulted in a final sample of 121 firms.

\section{Regression Models}

In addition to the AIMR ratings requirements, all firms evaluated were required to have data listed on the annual active and research Compustat database. A multivariate analysis is used to test the hypotheses identified in section II. These tests are based on the following four regression models and their variables:

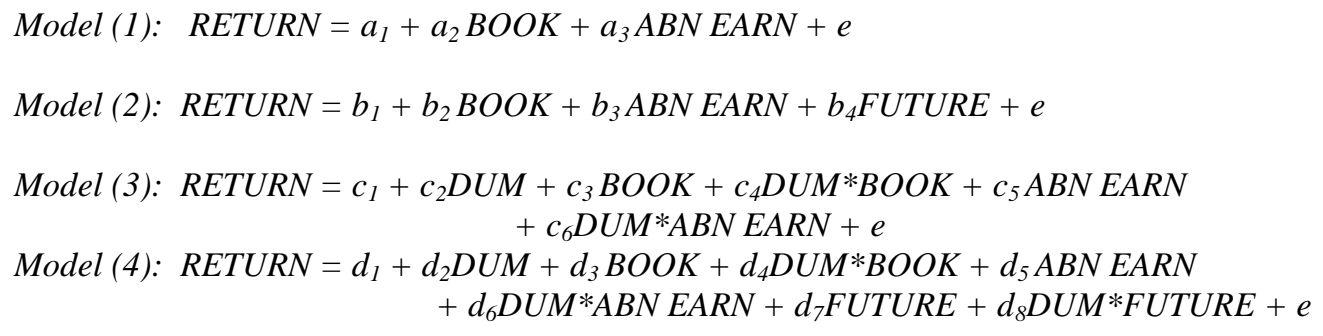

where RETURN is the annualized one year rate of return in percentage terms,

- DUM is an indicator variable that has a value of 1 if it expanded discretionary disclosures and 0 otherwise,

- $\quad$ BOOK is the book value of equity deflated by prior period price,

- $\quad$ ABN EARN is the change in current period earnings deflated by prior period price, and

- $\quad$ FUTURE is the subsequent period's earnings deflated by prior period price.

Models (1) and (2) are used to test the hypothesis using aggregated data for the pre and post-disclosure change years. The FUTURE variable in Model (2) is of interest for testing the first hypothesis. Support will be provided if firms increasing disclosures have a significantly higher level of future earnings (FUTURE) than those decreasing disclosures after the change. To test the second hypothesis the difference for the reported financial variable $B O O K$ and $A B N E A R N$ for each data group were analyzed. Support would be found if there was a significant difference for both variables, $B O O K$ and $A B N E A R N$, between the firms increasing disclosures and the firms decreasing disclosure in both Models (1) and (2).

Models (3) and (4) are used to test the hypotheses using yearly data with a dummy variable (DUM) used to distinguish between disclosure increasing and disclosure decreasing firms. Support for the first hypothesis is provided if the coefficient on the variable $D U M^{*} F U T U R E$, in Model (4), is positive and significant for only the post-disclosure years. Support for the second hypothesis is provided if the coefficient on the variables $D U M * B O O K$ and $D U M^{*} A B N E A R N$ are positive and significant in both Models (3) and (4) for only the post-disclosure years.

\section{Descriptive Statistics}

Table 1 provides descriptive statistics for both the firms that had sustained increases in their discretionary disclosures and the firms who had sustained decreases in their discretionary disclosures. Similar to Healy et al. (1999), the observations were aggregated for the pre-disclosure change period and the post-disclosure change 
period. The post-disclosure change period consists of the year of change in disclosures and the subsequent two years, while the pre-disclosure period consists of the two years prior to the year of change. The SIZE variable would indicate that the firms being evaluated are relatively large companies. This would seem reasonable, as the AIMR generally examines firms that would be large enough to attract sufficient analyst following.

Table 1: Descriptive Statistics (Aggregated for Pre- and Post-disclosure Change Years)

\begin{tabular}{|c|c|c|c|c|}
\hline & \multicolumn{2}{|c|}{ Pre-disclosure Change } & \multicolumn{2}{|c|}{ Post-disclosure Change } \\
\hline $\begin{array}{l}\text { VARIABLES }^{\mathbf{b}} \\
\text { (mean values) }^{\text {man }}\end{array}$ & Decrease $^{c}$ & Increase $^{c}$ & Decrease $^{c}$ & Increase $^{c}$ \\
\hline SIZE & $9,790.0$ & $8,173.3$ & $11,932.9$ & $9,468.6$ \\
\hline BOOK & 0.6827 & $0.5893^{\mathrm{a}}$ & 0.6190 & $0.5359^{\mathrm{a}}$ \\
\hline ABN EARN & -0.0015 & 0.0078 & -0.0016 & 0.0057 \\
\hline FUTURE & 0.0596 & $0.0848^{\mathrm{a}}$ & 0.0243 & $0.0714^{\mathrm{a}}$ \\
\hline RETURN & 15.604 & 18.841 & 10.314 & $19.594^{\mathrm{a}}$ \\
\hline CRR & N/A & N/A & -42.5 & 44.7 \\
\hline $\mathrm{N}$ & 218 & 228 & 330 & 340 \\
\hline
\end{tabular}

Signifies that the difference between the Increase and Decrease classifications are significant at the $\mathrm{p}<0.01$ level.

b Variables are defined as follows: SIZE is the average total assets (in millions), BOOK is the book value of equity deflated by prior period price, ABN EARN is the change in current period earnings deflated by prior period price, FUTURE is the subsequent period's earnings deflated by prior period price, RETURN is the annualized one year rate of return in percentage terms, and CRR is the change in relative disclosure rankings.

c Increase is the category of firms that expanded their discretionary disclosures, and Decrease is the category of firms that reduced their discretionary disclosures.

The future earnings of the firms (FUTURE) were significantly higher for the Increase firms both prior to and subsequent to the change in disclosures. However, annualized stock returns (RETURN) were higher for the Increase firms only following the change in disclosures. Further analysis reveals that the difference is due more to the decline in returns for the Decrease group. However, because the returns measurement is not market-adjusted, we are unable to make any inferences as to whether it is because the Decrease firms had relatively poor performance or if the Increase firms had relatively good performance. This does provide some support for Hypothesis 1, as the Increase firms had a significantly higher level of future earnings relative to the Decrease firms. ${ }^{5}$

While BOOK (the book value of equity, deflated by prior period price) was significantly smaller for the Increase firms subsequent to the disclosure change, it was also significantly smaller prior to the disclosure change. This would not provide support that management increased disclosures in order to increase the market's perception of the value of the firm based on the book value of its equity. ${ }^{6}$ Furthermore, there is no difference between the Increase and Decrease groups as to the ABN EARN variable, either pre- or post-disclosure change. These would not provide support for Hypothesis 2 as the Increase firms do not exhibit a change in the reported financial variables relative to the Decrease firms.

\footnotetext{
${ }^{5}$ The Increase firms also had significantly higher FUTURE in the pre-disclosure business. However, this could actually provide additional support for Hypothesis 2. If a firm at the end of year -1 was expecting higher future earnings, management could signal this to the market by expanding its discretionary disclosure activities in order to capture the benefits from those higher future earnings.

${ }^{6}$ If the market was undervaluing the book value of a firm's equity, management would have incentive to expand disclosures to properly value the equity. In this instance, the Increase firms had a statistically smaller ratio both before and after the disclosure change. This lower value implies that the Increase firms' book value of equity received a higher market valuation both before and after the period of change.
} 
Table 2: Descriptive Statistics (Year-by-Year Basis)

\begin{tabular}{|c|c|c|c|c|c|}
\hline \multirow{2}{*}{$\begin{array}{c}\text { VARIABLES }^{\mathrm{d}} \\
\text { Relative Rankings } \\
\end{array}$} & \multicolumn{5}{|c|}{ Years Surrounding Disclosure Change } \\
\hline & Year -2 & Year -1 & Year 0 & Year +1 & Year +2 \\
\hline Increase $^{\mathrm{e}}$ & $25.18^{\mathrm{a}}$ & $33.65^{\mathrm{a}}$ & $63.98^{\mathrm{a}}$ & $71.95^{\mathrm{a}}$ & $74.13^{\mathrm{a}}$ \\
\hline Decrease $^{\mathrm{e}}$ & 73.35 & 66.61 & 34.32 & 30.56 & 27.49 \\
\hline \multicolumn{6}{|l|}{ RETURN } \\
\hline Increase $^{\mathrm{e}}$ & 21.69 & 16.07 & $20.95^{\mathrm{a}}$ & $23.88^{b}$ & 13.99 \\
\hline Decrease $^{\mathrm{e}}$ & 17.91 & 13.32 & 11.71 & 9.31 & 9.93 \\
\hline \multicolumn{6}{|l|}{ BOOK } \\
\hline Increase $^{\mathrm{e}}$ & $0.6077^{\mathrm{b}}$ & $0.5712^{b}$ & 0.5619 & 0.5506 & $0.4956^{\mathrm{a}}$ \\
\hline Decrease $^{\mathrm{e}}$ & 0.7046 & 0.6609 & 0.6342 & 0.6094 & 0.6134 \\
\hline \multicolumn{6}{|l|}{ ABN EARN } \\
\hline Increase $^{\mathrm{e}}$ & 0.0081 & 0.0076 & 0.0140 & $0.017^{\mathrm{b}}$ & -0.0078 \\
\hline Decrease $^{\mathrm{e}}$ & 0.0090 & -0.0120 & -0.0029 & -0.017 & 0.0155 \\
\hline \multicolumn{6}{|l|}{ FUTURE } \\
\hline Increase $^{\mathrm{e}}$ & 0.0858 & $0.0839^{\mathrm{a}}$ & $0.0855^{\mathrm{a}}$ & $0.0673^{\mathrm{a}}$ & $0.0611^{\mathrm{c}}$ \\
\hline Decrease $^{\mathrm{e}}$ & 0.0678 & 0.0514 & 0.0256 & 0.0267 & 0.0205 \\
\hline
\end{tabular}

a Signifies that the difference between the Increase and Decrease classifications are significant at the p<0.01 level (onetailed).

b Signifies that the difference between the Increase and Decrease classifications are significant at the p<0.05 level (onetailed).

c Signifies that the difference between the Increase and Decrease classifications are significant at the $\mathrm{p}<0.10$ level (onetailed).

d Variables are defined as follows: Relative Rankings are the disclosure scores of the AIMR ranked according to equation (5), RETURN is the annualized one year rate of return in percentage terms, BOOK is the book value of equity deflated by prior period price, ABN EARN is the change in current period earnings deflated by prior period price, and FUTURE is the subsequent period's earnings deflated by prior period price.

e Increase is the category of firms that expanded their discretionary disclosures, and Decrease is the category of firms that reduced their discretionary disclosures.

Table 2 provides descriptive statistics on a year-by-year basis in order to better evaluate the factors that may affect management's disclosure decision. While the relative rankings were significantly different in all of the years reported, the RETURN variable was only significantly different in years 0 and +1 . We can then assume that the Increase and Decrease firms had similar market success prior to the change in disclosures, but the Increase firms did benefit from the expanded disclosures in the first two years of change. Because there is no difference between Increase and Decrease in year +2 , we could infer that either there were no additional benefits to expanded disclosure for Increase firms or the Increase firms had to maintain its disclosure policy to retain the prior period gains.

The FUTURE variable was significantly higher in years $-1,0,+1$, and +2 . This does provide support for the predictive nature of management's discretionary disclosures. Because management would be more knowledgeable as to future prospects, it is to their benefit to signal these future prospects to the market. In addition, the difference of the FUTURE variable in year -1 could explain why firms decide to change their discretionary disclosure activities. These findings provide support for Hypothesis 1.

The ABN EARN variable was only different in year +1 . Furthermore, the BOOK was significantly different prior to the disclosure change and only in year +2 . In addition, the BOOK was significantly lower, implying that the book value of equity is undervalued by the market. Some modest support, for the second hypothesis, could be found in that the expanded disclosures did eliminate the difference between the INCREASE and DECREASE firms in years 0 and +1 . Because the difference did persist after year +2 , it would appear that the level of feedback value was not significant. Therefore, there is little support for Hypothesis 2. 
Table 3: Regression Results (Aggregated Years)

Model (1): RETURN $=a_{1}+a_{2} B O O K+a_{3} A B N E A R N+e$

Model (2): RETURN $=b_{1}+b_{2}$ BOOK $+b_{3} A B N E A R N+b_{4} F U T U R E+e$

Panel A: Pre-disclosure Change

\begin{tabular}{|c|c|c|c|c|}
\hline & \multicolumn{2}{|c|}{ Equation (1) } & \multicolumn{2}{|c|}{ Equation (2) } \\
\hline Variable $^{d}$ & Increase $^{\mathrm{e}}$ & Decrease $^{e}$ & Increase & Decrease \\
\hline Intercept & $\begin{array}{l}9.56 \\
(2.1)\end{array}$ & $\begin{array}{l}10.23 \\
(2.6)\end{array}$ & $\begin{array}{c}4.7 \\
(1.0)\end{array}$ & $\begin{array}{c}7.0 \\
(1.8)\end{array}$ \\
\hline BOOK & $\begin{array}{l}14.5 \\
(2.2)\end{array}$ & $\begin{array}{l}8.09 \\
(1.6)\end{array}$ & $\begin{array}{l}12.3 \\
(1.9)\end{array}$ & $\begin{array}{c}7.5 \\
(1.5)\end{array}$ \\
\hline ABN EARN & $\begin{array}{l}90.9 \\
(4.3) \\
\end{array}$ & $\begin{array}{l}95.1 \\
(5.5) \\
\end{array}$ & $\begin{array}{l}80.1 \\
(3.9) \\
\end{array}$ & $\begin{array}{l}90.5 \\
(5.4) \\
\end{array}$ \\
\hline FUTURE & & & $\begin{array}{l}78.9 \\
(3.4) \\
\end{array}$ & $\begin{array}{l}59.6 \\
(3.8) \\
\end{array}$ \\
\hline $\begin{array}{l}\mathrm{R}^{2} \\
\text { Model F-stat }\end{array}$ & $\begin{array}{c}\mathrm{R}^{2}=.094 \\
\mathrm{~F}=12.80 \\
\mathrm{p}<.00\end{array}$ & $\begin{array}{c}\mathrm{R}^{2}=.134 \\
\mathrm{~F}=17.82 \\
\mathrm{p}<.00\end{array}$ & $\begin{array}{c}\mathrm{R}^{2}=.139 \\
\mathrm{~F}=13.06 \\
\mathrm{p}<.00\end{array}$ & $\begin{array}{c}\mathrm{R}^{2}=.185 \\
\mathrm{~F}=17.54 \\
\mathrm{p}<.00\end{array}$ \\
\hline Number & $\mathrm{n}=228$ & $\mathrm{n}=219$ & $\mathrm{n}=226$ & $\mathrm{n}=219$ \\
\hline
\end{tabular}

Panel B: Post-disclosure Change

\begin{tabular}{|c|c|c|c|c|}
\hline & \multicolumn{2}{|c|}{ Equation (1) } & \multicolumn{2}{|c|}{ Equation (2) } \\
\hline Variable $^{d}$ & Increase $^{\mathrm{e}}$ & Decrease $^{\mathrm{e}}$ & Increase & Decrease \\
\hline Intercept & $\begin{array}{l}12.3 \\
(3.2) \\
\end{array}$ & $\begin{array}{c}6.5 \\
(2.1) \\
\end{array}$ & $\begin{array}{c}0.7 \\
(0.2) \\
\end{array}$ & $\begin{array}{c}7.5 \\
(2.4) \\
\end{array}$ \\
\hline BOOK & $\begin{array}{l}12.9 \\
(2.9)\end{array}$ & $\begin{array}{c}6.2 \\
(1.4)\end{array}$ & $\begin{array}{c}9.5 \\
(1.7)\end{array}$ & $\begin{array}{c}3.5 \\
(0.8)\end{array}$ \\
\hline ABN EARN & $\begin{array}{l}69.1^{b} \\
(3.4)\end{array}$ & $\begin{array}{l}35.0 \\
(2.9)\end{array}$ & $\begin{array}{l}37.3 \\
(1.9)\end{array}$ & $\begin{array}{l}23.1 \\
(1.8)\end{array}$ \\
\hline FUTURE & & & $\begin{array}{l}197.1^{\mathrm{a}} \\
(7.6)\end{array}$ & $\begin{array}{l}28.7 \\
(2.8)\end{array}$ \\
\hline $\begin{array}{l}\mathrm{R}^{2} \\
\text { Model F-stat }\end{array}$ & $\begin{array}{c}\mathrm{R}^{2}=.026 \\
\mathrm{~F}=8.37 \\
\mathrm{p}<.00\end{array}$ & $\begin{array}{c}\mathrm{R}^{2}=.041 \\
\mathrm{~F}=5.46 \\
\mathrm{p}<.01\end{array}$ & $\begin{array}{c}\mathrm{R}^{2}=.046 \\
\mathrm{~F}=25.66 \\
\mathrm{p}<.00\end{array}$ & $\begin{array}{c}\mathrm{R}^{2}=.180 \\
\mathrm{~F}=6.28 \\
\mathrm{p}<.00\end{array}$ \\
\hline Number & $\mathrm{n}=343$ & $\mathrm{n}=333$ & $\mathrm{n}=339$ & $\mathrm{n}=331$ \\
\hline
\end{tabular}

Note: Coefficients (two-tailed t-statistics) are shown for each variable.

a Signifies that the difference between the Increase and Decrease classifications are significant at the $\mathrm{p}<0.01$ level (onetailed).

b Signifies that the difference between the Increase and Decrease classifications are significant at the $\mathrm{p}<0.05$ level (onetailed).

c Signifies that the difference between the Increase and Decrease classifications are significant at the p<0.10 level (onetailed).

d Variables are defined as follows: RETURN is the annualized one year rate of return in percentage terms, BOOK is the book value of equity deflated by prior period price, ABN EARN is the change in current period earnings deflated by prior period price, and FUTURE is the subsequent period's earnings deflated by prior period price.

e Increase is the category of firms that expanded their discretionary disclosures, and Decrease is the category of firms that reduced their discretionary disclosures.

\section{RESULTS}

Table 3 presents the regression results for Model (1) and (2). Panel A shows the pre-disclosure change results and Panel B shows the post-disclosure change results. All equations tested were statistically significant. The results for Model (1) examined the effect on the reported financial results only. The effect of the disclosure change can be made by comparing coefficients between the two groups. Model (2) adds the FUTURE variable to proxy for the predictive information possessed in the discretionary disclosures. Similar to previous results, Model (1) has no difference in coefficients, either pre- or post-disclosure change, except for the variable ABN EARN in the post- 
disclosure group. That has led to prior conclusions that firms expand disclosures when current abnormal earnings are undervalued by the market and there is no support found for the second hypothesis. By adding the FUTURE variable in Model (2), we see that there is no difference in coefficients between the INCREASE and DECREASE firms except for the FUTURE variable in the post-disclosure change group. This provides support for Hypothesis 1.

Table 4: Ohlson Model Regression (Individual Years)

Model (3): RETURN $=c_{1}+c_{2} D U M+c_{3} B O O K+c_{4} D U M * B O O K+c_{5} A B N E A R N$

$+c_{6} D U M^{*} A B N E A R N+e$

\begin{tabular}{|c|c|c|c|c|c|}
\hline Variable $^{\mathrm{a}}$ & Year -2 & Year -1 & Year 0 & Year +1 & Year +2 \\
\hline Intercept & $\begin{array}{l}5.76 \\
(0.9)\end{array}$ & $\begin{array}{l}15.43 \\
(2.5)\end{array}$ & $\begin{array}{l}14.42 \\
(2.2)\end{array}$ & $\begin{array}{l}7.51 \\
(1.3)\end{array}$ & $\begin{array}{l}-0.53 \\
(-0.1)\end{array}$ \\
\hline DUM & $\begin{array}{l}5.96 \\
(0.7)\end{array}$ & $\begin{array}{l}-7.54 \\
(-0.9)\end{array}$ & $\begin{array}{l}-0.69 \\
(-0.1)\end{array}$ & $\begin{array}{l}0.29 \\
(0.1)\end{array}$ & $\begin{array}{l}19.86 \\
(2.4)\end{array}$ \\
\hline$\overline{\mathrm{BOOK}}$ & $\begin{array}{l}16.00 \\
(2.1)\end{array}$ & $\begin{array}{l}-1.48 \\
(-0.2) \\
\end{array}$ & $\begin{array}{l}-4.17 \\
(-0.5)\end{array}$ & $\begin{array}{l}4.52 \\
(0.6)\end{array}$ & $\begin{array}{l}16.67 \\
(2.4)\end{array}$ \\
\hline DUM*BOOK & $\begin{array}{l}-1.23 \\
(-0.1)\end{array}$ & $\begin{array}{l}14.83 \\
(1.2)\end{array}$ & $\begin{array}{l}16.22 \\
(1.2)\end{array}$ & $\begin{array}{c}23.02 \\
(1.8)\end{array}$ & $\begin{array}{l}-25.11 \\
(-1.9)\end{array}$ \\
\hline ABN EARN & $\begin{array}{l}98.19 \\
(3.5)\end{array}$ & $\begin{array}{l}95.2 \\
(3.7)\end{array}$ & $\begin{array}{c}22.92 \\
(0.8)\end{array}$ & $\begin{array}{l}55.16 \\
(2.5)\end{array}$ & $\begin{array}{l}14.99 \\
(0.8)\end{array}$ \\
\hline $\begin{array}{l}\text { DUM * } \\
\text { ABN EARN }\end{array}$ & $\begin{array}{c}25.06 \\
(0.6)\end{array}$ & $\begin{array}{l}-30.8 \\
(-0.9)\end{array}$ & $\begin{array}{l}7.60 \\
(0.2)\end{array}$ & $\begin{array}{l}30.58 \\
(0.8)\end{array}$ & $\begin{array}{c}134.03 \\
(2.5)\end{array}$ \\
\hline $\begin{array}{l}\mathrm{R}^{2} \\
\text { Model F-stat }\end{array}$ & $\begin{array}{c}\mathrm{R}^{2}=.134 \\
\mathrm{~F}=7.84 \\
\mathrm{p}<.00\end{array}$ & $\begin{array}{c}\mathrm{R}^{2}=.079 \\
\mathrm{~F}=4.86 \\
\mathrm{p}<.00\end{array}$ & $\begin{array}{l}\mathrm{R}^{2}=.013 \\
\mathrm{~F}=1.59 \\
\mathrm{p}=\mathrm{n} . \mathrm{s} .\end{array}$ & $\begin{array}{c}\mathrm{R}^{2}=.116 \\
\mathrm{~F}=6.87 \\
\mathrm{p}<.00\end{array}$ & $\begin{array}{c}\mathrm{R}^{2}=.057 \\
\mathrm{~F}=3.70 \\
\mathrm{p}<.01\end{array}$ \\
\hline Number & $\mathrm{n}=222$ & $\mathrm{n}=225$ & $\mathrm{n}=225$ & $\mathrm{n}=225$ & $\mathrm{n}=226$ \\
\hline
\end{tabular}

Note: Coefficients (two-tailed t-statistics) are shown for each variable.

a Variables are defined as follows: RETURN is the annualized one year rate of return in percentage terms, DUM is an indicator variable that has a value of 1 if it expanded discretionary disclosures and 0 otherwise, BOOK is the book value of equity deflated by prior period price, $\mathrm{ABN}$ EARN is the change in current period earnings deflated by prior period price, and FUTURE is the subsequent period's earnings deflated by prior period price.

Tables 4 and 5 present the individual year results for Models (3) and (4), respectively. By using dummy variables, we are able to evaluate both the Increase and Decrease firms in the same regression results. As to the results for Model (3) in Table 4, the Year 0 results were not statistically significant, while all other years were significant at the $\mathrm{p}<.01$ level. In testing Hypothesis 2, we see that ABN EARN was only different between the two groups in Year +2 . Furthermore, the BOOK variable was significantly different in Years +1 and +2 , but with opposite signs in the two years. These year-by-year results provide little support for value of expanded disclosures. As to the results for Model (4) as reported in Table 5, we see that all years were significant at the p<.01 level. In testing Hypothesis 1, we see that the FUTURE variable was significantly higher for the INCREASE firms (DUM*FUTURE) for all three post-disclosure years. This provides strong support for Hypothesis 1 that the expanded disclosures are focused on providing information containing predictive value. In testing Hypothesis 2, the ABN EARN was significantly higher only in Year +2 and BOOK was higher only in Year +1 for the INCREASE firms. This would provide little support for Hypothesis 2 that the expanded disclosures provide information containing feedback value. 
Table 5: Modified Ohlson Model Regression (Individual Years)

Model (4): RETURN $=d_{1}+d_{2} D U M+d_{3} B O O K+d_{4} D U M * B O O K+d_{5} A B N E A R N$

$+d_{6} D U M * A B N E A R N+d_{7} F U T U R E+d_{8} D U M * F U T U R E+e$

\begin{tabular}{|c|c|c|c|c|c|}
\hline Variable $^{d}$ & Year -2 & Year -1 & Year 0 & Year +1 & Year +2 \\
\hline Intercept & $\begin{array}{l}3.59 \\
(0.6)\end{array}$ & $\begin{array}{l}9.15 \\
(1.5) \\
\end{array}$ & $\begin{array}{l}10.56 \\
(1.7)\end{array}$ & $\begin{array}{l}8.28 \\
(1.5) \\
\end{array}$ & $\begin{array}{l}0.80 \\
(0.2) \\
\end{array}$ \\
\hline DUM & $\begin{array}{l}5.55 \\
(0.6)\end{array}$ & $\begin{array}{l}-9.39 \\
(-1.1)\end{array}$ & $\begin{array}{c}-18.99 \\
(-2.0)\end{array}$ & $\begin{array}{l}-11.3 \\
(-1.4)\end{array}$ & $\begin{array}{l}11.34 \\
(1.3)\end{array}$ \\
\hline BOOK & $\begin{array}{l}14.75 \\
(1.9)\end{array}$ & $\begin{array}{l}0.74 \\
(0.1)\end{array}$ & $\begin{array}{l}-0.99 \\
(-0.1)\end{array}$ & $\begin{array}{l}1.02 \\
(0.1)\end{array}$ & $\begin{array}{l}14.31 \\
(2.0)\end{array}$ \\
\hline DUM*BOOK & $\begin{array}{l}-3.10 \\
(-0.3)\end{array}$ & $\begin{array}{l}12.59 \\
(1.1)\end{array}$ & $\begin{array}{l}2.10 \\
(0.2) \\
\end{array}$ & $\begin{array}{l}26.09 \\
(2.2) \\
\end{array}$ & $\begin{array}{r}-22.97 \\
(-1.8)\end{array}$ \\
\hline ABN EARN & $\begin{array}{c}105.51 \\
(3.8)\end{array}$ & $\begin{array}{c}69.49 \\
(2.7)\end{array}$ & $\begin{array}{l}11.12 \\
(0.4)\end{array}$ & $\begin{array}{l}49.46 \\
(2.4)\end{array}$ & $\begin{array}{l}9.22 \\
(0.4)\end{array}$ \\
\hline $\begin{array}{l}\text { DUM * } \\
\text { ABN EARN }\end{array}$ & $\begin{array}{l}9.71 \\
(0.2)\end{array}$ & $\begin{array}{c}-19.98 \\
(-0.6)\end{array}$ & $\begin{array}{l}14.66 \\
(0.4)\end{array}$ & $\begin{array}{l}-19.75 \\
(-0.5)\end{array}$ & $\begin{array}{c}99.81 \\
(1.8)\end{array}$ \\
\hline FUTURE & $\begin{array}{c}43.99 \\
(1.9) \\
\end{array}$ & $\begin{array}{l}87.73 \\
(3.3) \\
\end{array}$ & $\begin{array}{l}70.56 \\
(2.7) \\
\end{array}$ & $\begin{array}{c}47.50 \\
(2.6) \\
\end{array}$ & $\begin{array}{l}10.60 \\
(0.7)\end{array}$ \\
\hline DUM * FUTURE & $\begin{array}{l}15.21 \\
(0.4)\end{array}$ & $\begin{array}{l}16.55 \\
(0.4)\end{array}$ & $\begin{array}{c}261.12 \\
(4.3)\end{array}$ & $\begin{array}{c}126.11 \\
(2.9)\end{array}$ & $\begin{array}{c}126.03 \\
(2.6)\end{array}$ \\
\hline $\begin{array}{l}\mathrm{R}^{2} \\
\text { Model F-stat }\end{array}$ & $\begin{array}{c}\mathrm{R}^{2}=.159 \\
\mathrm{~F}=6.94 \\
\mathrm{p}<.00\end{array}$ & $\begin{array}{c}\mathrm{R}^{2}=.159 \\
\mathrm{~F}=7.01 \\
\mathrm{p}<.00\end{array}$ & $\begin{array}{c}\mathrm{R}^{2}=.175 \\
\mathrm{~F}=7.77 \\
\mathrm{p}<.00\end{array}$ & $\begin{array}{c}\mathrm{R}^{2}=.201 \\
\mathrm{~F}=9.06 \\
\mathrm{p}<.00\end{array}$ & $\begin{array}{c}\mathrm{R}^{2}=.087 \\
\mathrm{~F}=3.99 \\
\mathrm{p}<.00\end{array}$ \\
\hline Number & $\mathrm{n}=221$ & $n=224$ & $\mathrm{n}=225$ & $\mathrm{n}=225$ & $\mathrm{n}=220$ \\
\hline
\end{tabular}

Note: Coefficients (two-tailed t-statistics) are shown for each variable.

a Variables are defined as follows: RETURN is the annualized one year rate of return in percentage terms, DUM is an indicator variable that has a value of 1 if it expanded discretionary disclosures and 0 otherwise, BOOK is the book value of equity deflated by prior period price, ABN EARN is the change in current period earnings deflated by prior period price, and FUTURE is the subsequent period's earnings deflated by prior period price.

\section{CONCLUSIONS AND LIMITATIONS}

This study examines the information benefits associated with firm's discretionary disclosures. Many studies have considered the benefits associated with increased discretionary disclosures (for example, Botosan and Plumlee 2002; Healy et. al 1999; Welker 1995; and others). By using the Ohlson Model (Ohlson 1995; Feltham and Ohlson 1995), our study examines the role of discretionary disclosures in a theoretical model, focusing on the relevant characteristics of accounting information. Furthermore, our study attempts to identify if the relevant information contained in the expanded discretionary disclosures possesses predictive value, feedback value, or both. Our tests demonstrated that the expanded firm disclosures did possess predictive value, but they did not possess significant feedback value.

These findings are important from a policy-setting perspective. As the FASB and other authoritative bodies attempt to mandate additional required disclosures, these bodies must understand that there are different costs associated with them. In this study, the primary relevant information possessed in the expanded disclosures was predictive value. By mandating such disclosures, there would be additional inherent costs due to the futuristic nature of the information. Furthermore, if the argument was to mandate additional disclosures that do not possess predictive value, it may be questionable whether the benefits from feedback value would exceed preparation costs.

One of the limitations to this study is the data. The AIMR discontinued its ratings program, so more recent evaluations cannot be completed. However, there have been no significant changes in the levels and types of mandated disclosures since the discontinuance. So from a policy-perspective, the desired qualities of information have not changed since that time. A second limitation is the evaluation of expanded disclosures from the perspective of the AIMR. Our findings were that the expanded disclosures consisted primarily of predictive value and did not possess feedback value. Because the AIMR consists of investment analysts, it is not surprising that they would desire disclosures that were more forward-looking. Therefore, their ratings may be skewed to firms, not 
based on the abundance of disclosures, but based on the abundance of forward-looking disclosures. It is important to consider that possibility when discussing the benefits, as well as the costs, associated with expanded discretionary disclosure.

The types and amounts of disclosures associated with financial reporting are extremely important when considering accounting policy. It is important for future research to further segregate the different types of disclosures based on their information qualities. In that way, accounting standard-setting can better understand the benefits and costs associated with additional disclosures. Another future consideration is the ranking of disclosure quality by user groups other than financial analysts. This will allow research to better meet the objectives of the Jenkins Committee, by identifying the information that users desire and the extent to which auditors should report on this information.

\section{AUTHOR INFORMATION}

Kevin Berry, Ph.D., is an Associate Professor of Accounting and Associate Dean at the University of Alaska Fairbanks. He has published in numerous journals including Journal of Business Finance \& Accounting, Journal of Accounting Education, Journal of Accounting Case Research, Petroleum Accounting and Financial Management Journal, The Mid-Atlantic Journal of Business, and International Journal of Accounting, Auditing and Performance Evaluation. He received his doctorate in accounting from Oklahoma State University.

William E. Wilcox, Ph.D., is an Assistant Professor in the School of Accounting and Computer Information Systems in the Monfort College of Business at the University of Northern Colorado in Greeley, Colorado. He earned a doctorate of accountancy from the University of Nebraska-Lincoln. His primary area of research is capital market studies, with publications in journals such as Advances in Accounting, Journal of Accounting and Public Policy, International Journal of Accounting and Finance, and Issues in Accounting Education.

David O'Bryan, Ph.D., CPA, CFE, CMA, is a Professor in the Department of Accounting at Pittsburg State University in Pittsburg, Kansas. He earned a doctorate in accountancy from the University of Missouri at Columbia in 1992. His teaching areas include Financial Accounting, Financial Statement Analysis, Fraud Examination, and Management Control Systems. He has published numerous journal articles including publications in the Journal of Accounting Education, Behavioral Research in Accounting, Journal of Business Finance \& Accounting, Advances in Accounting, Journal of Accounting Case Research, and the Journal of Energy Finance \& Development.

Jeffrey J. Quirin, Ph.D., CMA, is an Associate Professor in the School of Accountancy at Wichita State University in Wichita, Kansas. He earned a doctorate in Accountancy from the University of Nebraska-Lincoln in 1998. His teaching areas include Financial Accounting and Managerial Accounting. He has published numerous journal articles including publications in the Accounting, Organizations \& Society, Issues in Accounting Education, Journal of Accounting Education, Behavioral Research in Accounting, Journal of Business Finance \& Accounting, Advances in Accounting, and the Journal of Accounting Case Research.

\section{REFERENCES}

1. Association for Investment Management and Research. Report of the Association for Investment Management and Research Corporate Information Committee Report. New York, NY: 1982-1993.

2. Botosan, C. 1997. Disclosure Level and the Cots of Equity Capital. The Accounting Review. 72: $323-349$.

3. Botosan, C. and M. Plumlee. 2002. A Re-examination of Disclosure Level and the Expected Cost of Capital. Journal of Accounting Research. 40: 21-40.

4. Chen, S., M. DeFond, and C. Park. 2002. Voluntary Disclosure of Balance Sheet Information in Quarterly Earnings Announcements. Journal of Accounting and Economics. 33: 29-251.

5. Diamond, D. and R. Verrecchia. 1991. Disclosure, Liquidity, and the Cost of Capital. Journal of Finance. 66: $1325-1355$.

6. Dutta, S. and B. Trueman. 2002. The Interpretation of Information and Corporate Disclosure Strategies. Review of Accounting Studies. 7: 1380-6653. 
7. Feltham, G. and J. Ohlson. 1995. Valuation and Clean Surplus Accounting for Operating and Financial Activities. Contemporary Accounting Research. 11: 689-732.

8. Healy, P., A. Hutton, and K. Palepu. 1999. Stock Performance and Intermediation Changes Surrounding Sustained Increases in Disclosure. Contemporary Accounting Research. 16: 485-520.

9. Healy, P. and K. Palepu 1993. The Effect of Firms' Financial Disclosure Strategies on Stock Prices. Accounting Horizons. 7: 1-11.

10. Lang, M. and R. Lundholm. 1993. Cross-Sectional Determinants of Analysts Ratings of Corporate Disclosures. Journal of Accounting Research. 31: 246-271.

11. Lundhlom, R. 1995. A Tutorial on the Ohlson and Feltham/Ohlson Models: Answers to some Frequently asked Questions. Contemporary Accounting Research. 11: 749 - 762.

12. Nagar, V., D. Nanda, and P. Wysocki. 2003. Discretionary Disclosure and Stock-Based Incentives. Journal of Accounting and Economics. 34: 283-309.

13. Ohlson, J. 1995. Earnings, Book Value and Dividends in Security Valuation. Contemporary Accounting Research. 11: 661-687.

14. Pae, S. 2002. Discretionary Disclosure, Efficiency, and Signal Informativeness. Journal of Accounting and Economics. 33: 279-311.

15. Poshakwale, S. and J. Courtis. 2005. Disclosure Level and Cost of Equity Capital: Evidence from the Banking Industry. Managerial and Decision Economics. 26: 431-444.

16. Sengupta, P. 1998. Corporate Disclosure and the Cost of Debt. The Accounting Review. 73: 459-475.

17. Shaw, K. 2003. Corporate Disclosure Quality, Earnings Smoothing, and Earnings' Timeliness. Journal of Business Research. 56: 1043-1050.

18. Sloan, R. 1996. Do Stock Prices Fully Reflect Information in Accruals and Cash Flows About Future Earnings? The Accounting Review. 71: 289-315.

19. Verrecchia, R. 1990. Endogenous proprietary costs through firm interdependence. Journal of Accounting and Economics. 12: 245-250.

20. Welker, M. 1995. Disclosure Policy, Information Asymmetry and Liquidity in Equity Markets. Contemporary Accounting Research. 11: 801-827. 